\title{
Syntactic Mapping of Preverbal Subject Positions in Standard Arabic
}

\author{
Feras Saeed \\ Qassim University, KSA
}

\begin{abstract}
In this paper, I argue for a new analysis of preverbal subject positions in Standard Arabic and claim that the subject in SV order can appear in two different positions. To support my analysis, I examine the distribution of preverbal subjects in Standard Arabic vis-à-vis negation markers, adverbial phrases, auxiliaries, floating quantifiers, emphatic reflexives, and apposition structures. In this respect, I introduce a new analysis in which I argue that there exist two syntactic positions for the preverbal subject in Standard Arabic, namely spec-TP, which hosts lower grammatical subjects, and spec-SubjP, which hosts higher subjects of predication, along lines discussed in Cardinaletti (2004). The corollary of this investigation leads to a syntactic mapping of the inventory of functional categories that can project between $\mathrm{CP}$ and $\mathrm{TP}$, and provides a minimal account for parametric differences in preverbal subject positions in other related languages.
\end{abstract}

\footnotetext{
Feras Saeed

Unaizah Community College, Unaizah City - 51911, Qassim, KSA

Phone: +966504620523; Email: ferasaeed@yahoo.com
} 
136 Syntactic Mapping of Preverbal Subject Positions in Standard Arabic

Keywords: subject positions, syntactic mapping, functional categories, negation markers, adverbial phrases, Standard Arabic

\section{Introduction}

A universal property of languages that has been documented in the literature is 'free inversion' between the subject and the verb (Kotzoglou 2006). In head-initial languages, e.g., Standard Arabic, the free inversion property is used more than often and the subject can, in several contexts, precede or follow the verb (Fassi Fehri 1993, Ouhalla 1994, Ryding 2005):
(1) qaraa
Sayf-un
kitaab-an.
read-sg ${ }^{42}$
Sayf-nom
book-acc
'Sayf read a book.'
(2) Sayf-un
qara-a
kitaab-an.
Sayf-nom
read-sg
book-acc
'Sayf read a book.'

However, when other syntactic categories, e.g., negation, appear with the preverbal subject in this language, the latter can surface in two different syntactic positions (Aoun et al. 2010, Fassi Fehri 2012):

\footnotetext{
42 The following abbreviations will be used throughout the paper: nom = nominative Case; acc $=$ accusative Case; gen $=$ genitive Case; $1=$ first person; $2=$ second person; $3=$ third person; $\mathrm{sg}=$ singular number; $\mathrm{pl}=$ plural number; $\mathrm{C}=$ complementiser.
} 
$\begin{array}{llll}\text { (3) ma } & \text { ana } & \text { faal-tu } & \text { hatha. } \\ \text { not } & \text { I } & \text { did-1sg } & \text { this }\end{array}$

'I did not do this.'

(4) ana ma faal-tu hatha.

I not did-1sg this

'I did not do this.'

Also, the preverbal subject in this language can precede or follow a preverbal adverb:

(5) fajatan Sayf-un nasiya kullashay. suddenly Sayf-nom forgot everything 'Suddenly Sayf forgot everything.'

(6) Sayf-un fajatan nasiya kullashay. Sayf-nom suddenly forgot everything 'Sayf suddenly forgot everything.'

In addition, this alternative position for the preverbal subject in Standard Arabic is available when the subject appears with auxiliaries:

(7) kaana Sayf-un yaktubu resaalatan.

was Sayf-nom write letter

'Sayf was writing a letter.'

(8) Sayf-un kaana yaktubu resaalat-an.

Sayf-nom was write letter-acc

'Sayf was writing a letter.' 
Moreover, there are constructions in the language in which two surface DPs appear preceding the verb, which independently argue for the availability of two preverbal syntactic positions to host different types of DPs. For example, the subject can appear with a floating quantifier in a preverbal position:

$\begin{array}{llll}\text { al-awlaad-u } & \text { ajmauun } & \text { hadhar-uu } & \text { n-nadwat-a. } \\ \text { the-boys-nom } & \text { all } & \text { attended-3pl } & \text { the-seminar-acc }\end{array}$
'The boys all attended the seminar.'

It is to be noticed that the two DPs preceding the verb are both below the CP projection (cf. Cardinaletti 1997, Cinque 1999):

(10) inna l-awlaad-a ajmauun hadhar-uu n-nadwat-a. $\mathrm{C}$ the-boys-acc all attended-3pl the-seminar-acc 'Indeed, the boys all attended the seminar.'

In the same manner, subject DPs can appear side by side with emphatic reflexives:
(11)
Sayf-un
nafsa-hu
katab-a
maqaal-an.
Sasyf-nom self-him wrote-3sg
essay-acc
'Sayf himself wrote an essay.'

Again, the preverbal DP and the reflexive are both below CP:

$\begin{array}{lcccc}\text { la'alla } & \text { Sayf-an } & \text { nafsa-hu } & \text { katab-a } & \text { maqaal-an. } \\ \text { C } & \text { Sasyf-acc } & \text { self-him } & \text { wrote-3sg } & \text { essay-acc } \\ \text { 'Perhaps } & \text { Sayf himself wrote an essay.' }\end{array}$


Moreover, preverbal subjects can appear with another emphatic DP or what is termed in Arabic grammar albadal 'apposition':

(13) Copenhagen al-aasema shahed-at huruuban adeeda. Copenhagen the-capital witnessed-3sg wars several 'Copenhagen, the capital, witnessed several wars.'

Similarly, the apposition construction can be preceded by a complementiser, indicating that both DPs are below the CP projection:

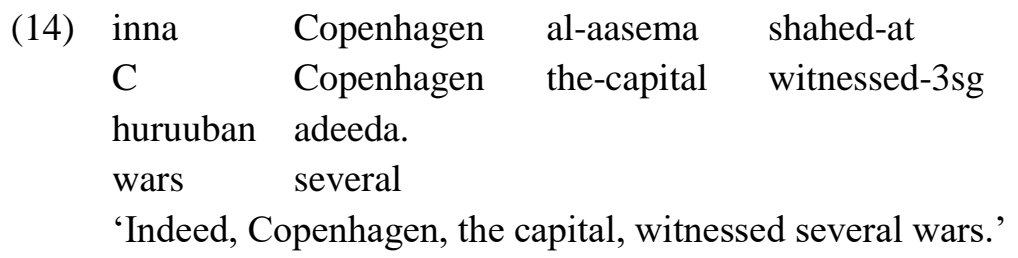

The linguistic research that has been done on the position of the preverbal subject in Standard Arabic has assumed that this language can have only one fixed preverbal position, i.e., spec-TP (or specAgrP in the old configuration) (Fassi Fehri 1993, Ouhalla 1994, Shlonsky 1997, Benmamoun 2000, Aoun et al. 2010, among others). This study has several lines of inquiry into the possible syntactic positions of preverbal subjects in Standard Arabic. This can be achieved through a detailed investigation of the subject interaction with other categories like negation, auxiliaries, adverbs, quantifiers, reflexives, and appositions. I will show that the subject in this language can appear in more than one position when it is preverbal (cf. Belletti 2004, Cardinaletti 2004). This claim will eventually result in a better understanding of the syntactic configuration of the 
area between the $\mathrm{CP}$ and TP heads.

The second section in this paper briefly outlines the proposal developed in Cardinaletti (2004) where she argues for the existence of two preverbal projections for the subject.

The third section looks at the two possible positions of preverbal subjects in Standard Arabic and their interaction with three different syntactic categories. The first subsection examines the relation between preverbal subjects and certain sentential negation particles in this language. The second subsection investigates the interaction between preverbal subjects and adverbs. The third subsection addresses the issue of the interaction between the preverbal subject and auxiliary verbs. In the fourth subsection, I introduce a new analysis in which I argue that there exist two syntactic positions for the preverbal subject in Standard Arabic, along lines discussed in Cardinaletti (2004).

The fourth section examines different contexts in Standard Arabic where the preverbal subject can appear with other XPs. In the first subsection, I examine the occurrence of subjects along with floating quantifiers. In the second subsection, I look at how preverbal subjects can surface with emphatic reflexives. In the third subsection, I investigate the apposition construction in Standard Arabic in which the preverbal subject surfaces with another DP and both refer to the same entity.

The fifth section summarises the main findings and claims argued for in the paper.

\section{Cardinaletti (2004)}

Cardinaletti starts her discussion of the cartography of preverbal 
subject positions by stating that the two main properties of subjects being the grammatical subject according to morphosyntactic criteria (checking nominative Case and phi-features) and being the semantic subject (the subject of predication) - are attributed to two distinct functional projections: AgrSP and SubjP, respectively. She argues that (2004: 121) "AgrSP is the projection in which phi-features are checked on nominative DPs; this results in nominative Case on the subject DP and verb agreement with the subject DP. SubjP is the projection in which the "subject-of-predication" feature is checked. In this way, the semantic property of subjects is encoded in the syntax through a morphosyntactic feature ... the two projections superficially host different types of subjects: while spec-SubjP typically hosts strong subjects, Spec-AgrSP typically hosts weak subjects".

These two functional projections that can host the preverbal subject, Cardinaletti points out, are actually below the lowest Compprojection FinP (Rizzi 1997); thus, both projections occur in the Infl domain. She provides a representational structure of these positions which, she argues, holds for all languages and does not distinguish between null subject languages and non-null subject languages (2004: 121):

(15) [[comp-domain ForceP TopP* FocusP FinP][Infl-domain SubjP AgrSP $\mathrm{TP}]$ [verb-domain VP]]

She puts forth the claim that if the two properties of subjects, which correspond to two distinct projections, are actually dissociated, we will have XPs that occur in subject position without checking nominative Case. To this end, she examines several constructions in which an XP different from the subject is fronted to the subject 
142 Syntactic Mapping of Preverbal Subject Positions in Standard Arabic

position. These constructions include dative fronting, locative fronting, and inverse copular sentences.

\subsection{Dative Fronting}

Cardinaletti argues that with Italian psych verbs either the theme or the experiencer can be preposed to the preverbal subject position (2004: 122):

\begin{tabular}{|c|c|c|c|c|c|c|}
\hline (16) & $\begin{array}{l}\text { la } \\
\text { the }\end{array}$ & $\begin{array}{l}\text { musica } \\
\text { music }\end{array}$ & $\begin{array}{l}\text { piaceva } \\
\text { pleased }\end{array}$ & $\begin{array}{l}\text { molto } \\
\text { much }\end{array}$ & $\begin{array}{l}\mathrm{a} \\
\text { to }\end{array}$ & $\begin{array}{l}\text { Gianni. } \\
\text { Gianni }\end{array}$ \\
\hline & 'Gia & liked m & ic a lot.' & & & \\
\hline (17) & & $\begin{array}{l}\text { Gianni } \\
\text { Gianni }\end{array}$ & $\begin{array}{l}\text { piaceva } \\
\text { pleased }\end{array}$ & $\begin{array}{l}\text { molto } \\
\text { much }\end{array}$ & $\begin{array}{l}\text { la } \\
\text { the }\end{array}$ & $\begin{array}{l}\text { musica } \\
\text { music }\end{array}$ \\
\hline
\end{tabular}

In the second example above, the fronted dative seems to be in the preverbal subject position, but it does not get its Case checked. This, she argues, makes its movement unmotivated. However, adopting the proposal of having two preverbal subject positions circumvents this problem, since we can argue that the fronted dative moves to the preverbal position in spec-SubjP to check the subject of predication feature, and the nominative Case is checked on the postverbal theme via a chain with the expletive pro. Thus, the dative argument appears preverbally, whereas the grammatical subject, a theme, stays in situ in postverbal position.

(18) $\left[\mathrm{SubjP}_{\mathrm{P}}\right.$ a Gianni $_{\mathrm{i}}\left[\mathrm{AgrSP} \operatorname{pro}_{\text {expl }}\right.$ piaceva $_{\mathrm{k}}\left[\right.$ molto $\left[\mathrm{VP} t_{\mathrm{i}} t_{\mathrm{k}}\right.$ la musica]]]] 


\subsection{Locative Fronting}

In Italian, unaccusative verbs allow their locative argument to be fronted to the subject position (Cardinaletti 2004: 124):

$\begin{array}{llllll}\text { su } & \text { Gianni } & \text { cadde } & \text { una } & \text { grande } & \text { disgrazia. } \\ \text { on } & \text { Gianni } & \text { fell } & \text { a } & \text { big } & \text { misfortune }\end{array}$

(20) essendo su Gianni caduta una grande disgrazia ... being on Gianni fallen a big misfortune ...

\subsection{Inverse Copular Sentences}

Cardinaletti argues that in inverse copular sentences in Italian, a predicative DP moves to the preverbal position, and the grammatical subject remains postverbally (2004: 125):

$\begin{array}{lllllll}\text { (21) la causa della rivolta } & \text { sono Gianni e } & \text { Maria. } \\ \text { the cause } & \text { of the riot } & \text { are } & \text { Gianni and Maria }\end{array}$

The example above can be assigned the following structure:

(22) [subjp la causa della rivolta ${ }_{\mathrm{i}}$ AgrSP $_{\text {pro }}$ roxpl $_{\text {eno }}$ [sc Gianni e Maria $\left.t_{\mathrm{i}}\right]$ ]]

Cardinaletti points out that the predicative DP moves to spec-SubjP, where it checks the subject-of predication feature. The grammatical subject remains in the postverbal position and gets nominative Case.

Cardinaletti (2004) concludes that dative and locative PPs and predicative DPs are not assigned nominative Case; therefore, their movement to spec-SubjP is not motivated. SubjP must contain some 
feature that attracts dative and locative PPs, predicative DPs, as well as subject DPs. The subject-of-predication feature represents what all these phrases have in common when they appear preverbally. The head Subj is thus the locus of the subject-of-predication feature.

\section{On Two Preverbal Positions}

In this section, I examine the possibility of having two different syntactic positions for the preverbal subject in Standard Arabic. Certain syntactic categories interact with the preverbal subject and show asymmetrical behaviour in some cases depending on the position of the subject.

\subsection{Preverbal Subject and Negation}

Negation in Standard Arabic can be expressed in the sentence by the occurrence of negation particles such as lam, lan, laa, and maa, among others (Ryding 2005). These particles can be categorised into three types; the first type includes negation particles like lam and lan that must be followed by the verb:

$\begin{array}{llll}\text { lam } & \text { taktub } & \text { Belqees-u } & \text { Belqees-u } \\ \text { didn't } & \text { write } & \text { Belqees-nom } & \text { essay-acc } \\ \text { 'Belqees did not write an essay.' } & \end{array}$

(24)
lan
yaktuba
Sayf-un
maqaal-an.
won't
write
Sayf-nom
essay-acc
'Sayf will not write an essay.' 
These negation particles cannot be followed by the subject, hence the ungrammaticality of the sentences below:

$\begin{array}{llll}\text { *lam } & \text { Belqees-u } & \text { taktub } & \text { maqaal-an. } \\ \text { didn't } & \text { Belqees-nom } & \text { write } & \text { essay-acc }\end{array}$

'Belqees did not write an essay.'

$\begin{array}{llll}\text { *lan } & \text { Sayf-un } & \text { yaktuba } & \text { maqaal-an. } \\ \text { won't } & \text { Sayf-nom } & \text { write } & \text { essay-acc } \\ \text { 'Sayf will not write an essay.' } & \end{array}$

However, subjects can precede both the negation particle and the verb:

(27)

$\begin{array}{llll}\text { Belqees-u } & \text { lam } & \text { taktub } & \text { maqaal-an. } \\ \text { Belqees-nom } & \text { didn't } & \text { write } & \text { essay-acc }\end{array}$

'Belqees did not write an essay.'

$\begin{array}{llll}\text { Sayf-un } & \text { lan } & \text { yaktuba } & \text { maqaal-an. } \\ \text { Sayf-nom } & \text { won't } & \text { write } & \text { essay-acc }\end{array}$

'Sayf will not write an essay.'

Following the standard analysis of verb movement in this language in which the verb is assumed to have vacated vP and left-adjoined the head T (Fassi Fehri 1993, Ouhalla 1994, Shlonsky 1997, Benmamoun 2000, among others), I assume that the subject DPs in the examples above cannot be positioned in spec-TP and must be based in a position higher than spec-TP.

The second type includes negation particles like maa that can be followed by the verb: 
146 Syntactic Mapping of Preverbal Subject Positions in Standard Arabic

(29) maa faala $\quad \begin{array}{ll}\text { Sayf-un } & \text { haatha. } \\ \text { not did } & \text { Sayf-nom } \\ \text { this }\end{array}$
'Sayf did not do this.'

$\begin{array}{llll}\text { (30) maa } & \text { kataba } & \text { al-walad-u } & \text { al-maqaal-a. } \\ \text { not } & \text { wrote } & \text { the-boy-nom } & \text { the-essay-acc }\end{array}$

'The boy did not write the essay.'

The negation particle maa can also be followed by the subject DP:

$\begin{array}{llll}\text { maa } & \text { ahad-un } & \text { faala } & \text { haatha. } \\ \text { not } & \text { one-nom } & \text { did } & \text { this } \\ \text { 'No one did this.' } & & \end{array}$

$\begin{array}{llll}\text { (32) maa taaleb-un } & \text { kataba } & \text { maqaal-an. } \\ \text { not } & \text { student-nom } & \text { wrote } & \text { essay-acc } \\ \text { 'No student wrote an essay.' } & \end{array}$

It is to be noticed that the Case of the subject is nominative, hence the ungrammaticality of the sentences below when the subject following the negation particle surfaces with an accusative Case marker:

$\begin{array}{llll}\text { *maa } & \text { ahad-an } & \text { faala } & \text { haatha. } \\ \text { not } & \text { one-acc } & \text { did } & \text { this }\end{array}$

'No one did this.'

$\begin{array}{llll}\text { (34) *maa } \quad \text { taaleb-an } \quad \text { kataba } & \text { maqaal-an. } \\ \text { not } & \text { student-acc } & \text { wrote } & \text { essay-acc } \\ \text { 'No student wrote an essay.' } & \end{array}$


Following the analysis that places negation above TP in Standard Arabic (Benmamoun 2000), I assume that the nominative subject DP that follows the negation particle maa must be in spec-TP.

The third type of negation includes particles like laa which can be followed by the subject ${ }^{43}$ :

$\begin{array}{llll}\text { laa } & \text { taaleb-a } & \text { yuhmelu } & \text { duruus-a-hu. } \\ \text { no } & \text { student-acc } & \text { neglects } & \text { lessons-acc-his }\end{array}$

'There is no student who neglects his lessons.'

$\begin{array}{llll}\text { laa } & \text { tefl-a } & \text { yuhebu } & \text { 1-haleeb-a. } \\ \text { no } & \text { child-acc } & \text { likes } & \text { the-milk-acc }\end{array}$

'There is no child who likes the milk.'

If the subject DP following the negation particle laa surfaces with a nominative Case marker, the sentence is rendered ungrammatical:

$\begin{array}{llll}* \text { laa } & \text { taaleb-u } & \text { yuhmelu } & \text { duruus-a-hu. } \\ \text { no } & \text { student-nom } & \text { neglects } & \text { lessons-acc-his }\end{array}$

'There is no student who neglects his lessons.'

$\begin{array}{llll}* \text { laa } & \text { tefl-u } & \text { yuhebu } & \text { 1-haleeb-a. } \\ \text { no } & \text { child-nom } & \text { likes } & \text { the-milk-acc }\end{array}$

'There is no child who likes the milk.'

In addition, the subject DP cannot precede the negation particle laa, hence the ungrammaticality of the sentences below:

43 An anonymous reviewer has rightly pointed out that the negation marker laa in the cited examples is a special marker that denotes categorical or absolute negation (Ryding 2005). 
148 Syntactic Mapping of Preverbal Subject Positions in Standard Arabic

$\begin{array}{llll}* \text { taaleb-un } & \text { laa } & \text { yuhmelu } & \text { duruus-a-hu. } \\ \text { student-nom } & \text { not } & \text { neglects } & \text { lessons-acc-his }\end{array}$

'There is no student who neglects his lessons.'

(40)

$\begin{array}{llll}* \text { tefl-un } & \text { laa } & \text { yuhebu } & \text { 1-haleeb-a. } \\ \text { child-nom } & \text { not } & \text { likes } & \text { the-milk-acc }\end{array}$

'There is no child who likes the milk.'

It is to be noticed that while the subject DP following the negation particle maa surfaces with a nominative Case marker, the subject following laa appears with an accusative Case marker. Moreover, while the negation particles lan and lam allow the subject to precede them, the particle la cannot be preceded by the subject. This variation in word order indicates that these different negation particles cannot occupy the same position above TP. There must be more than one position that can host negation particles. Also, the subject seems to occupy two different positions in its interaction with these negation particles.

\subsection{Preverbal Subject and Adverbs}

Adverbial phrases can project in several preverbal and postverbal positions in Standard Arabic. In preverbal positions, adverbs can appear in a sentence-initial position:

(41) fajatan dhaharat as-safeenat-u fi l-ufuq-i. suddenly appeared the-ship-nom in the-horizon-gen 'Suddenly the ship appeared in the horizon.'

In this context, the subject is in a postverbal position, presumably 
in spec-vP. This is the unmarked word order in Standard Arabic where the subject typically follows the verb. It has been argued that the verb in this language must vacate its base-position in the vP shell and left-adjoin a higher head, probably the head $\mathrm{T}$, and this obligatory head movement is motivated by the rich morphology on the verb (Fassi Fehri 1993, Ouhalla 1994, Shlonsky 1997, Benmamoun 2000, among others). Hence, the sentence-initial adverb could be in a position above TP in the example above.

The alternative marked word order in Standard Arabic is the SV order where the subject precedes the verb and ultimately lands in spec-TP, below the adverbial phrase:

(42) fajatan as-safeenat-u dhaharat fi l-ufuq-i.
suddenly the-ship-nom appeared in the-horizon-gen
'Suddenly the ship appeared in the horizon.'

In the example above the adverb precedes both the subject and the verb. However, the subject can surface in a position higher than the adverbial phrase:
as-safeenat-u fajatan dhaharat fi l-ufuq-i. the-ship-nom suddenly appeared in the-horizon-gen 'The ship suddenly appeared in the horizon.'

It can be seen in the example above that the subject precedes both the adverb and the verb. This position cannot be in the $\mathrm{CP}$ domain and the preverbal DP cannot be a topic, for the simple reason that the sentence above can appear with a sentence-initial complementiser (cf. McCloskey 1997, Rizzi 1997): 
150 Syntactic Mapping of Preverbal Subject Positions in Standard Arabic

\begin{tabular}{|c|c|c|c|c|}
\hline (44) & $\begin{array}{l}\text { inna } \\
\mathrm{C}\end{array}$ & $\begin{array}{l}\text { s-safeenat-a } \\
\text { the-ship-acc }\end{array}$ & $\begin{array}{l}\text { fajatan } \\
\text { suddenly }\end{array}$ & $\begin{array}{l}\text { dhaharat } \\
\text { appeared }\end{array}$ \\
\hline & & $\begin{array}{l}\text { 1-ufuq-i. } \\
\text { the-horizon-gen }\end{array}$ & & \\
\hline
\end{tabular}

In addition, the Case marker of the preverbal subject has changed to accusative, suggesting that this DP cannot be a topic since topics moving from a subject position typically leave a pronominal clitic and end up with a nominative Case marker:

as-safeenat-u inna-ha fajatan
the-ship-nom C-it
fi l-ufuq-i.
in the-horizon-gen

'The ship, indeed it suddenly appeared in the horizon.'

Consequently, we can assume that there exist two different positions for the preverbal subject in Standard Arabic. The first position is a specifier position below the adverbial phrase, and the second is a specifier position above the adverbial phrase.

\subsection{Preverbal Subject and Auxiliaries}

There are two types of auxiliaries in Standard Arabic, positive auxiliaries and negative auxiliaries. I will briefly outline below the distributional properties of the positive auxiliary kaan and the negative auxiliary laysa, as examples. The positive auxiliary has two forms: perfective kaan 'was' and imperfective yakuun 'is'. The imperfective form is not commonly used, except in certain cases. 
However, the negative auxiliary has only one imperfective form laysa 'isn't'. To express the perfective aspect of the negative auxiliary a negation particle is coupled with the positive auxiliary to form conjoined particles like lam yakuun 'wasn't'.

These auxiliaries can stand alone as main verbs in copular sentences where they agree with their subject:

$\begin{array}{lll}\text { kaan-a } & \text { l-walad-u } & \text { saeed-an. } \\ \text { was-sg.m } & \text { the-boy-nom } & \text { happy-acc }\end{array}$

'The boy was happy.'

$\begin{array}{lll}\text { laysa-t } \quad \text { il-fataat-u } & \text { hazeenat-an. } \\ \text { isn't-sg.f } & \text { the-girl-nom } & \text { sad-acc } \\ \text { 'The girl is not sad.' } & \end{array}$

When these auxiliaries appear with main verbs, they still inflect for agreement:

$\begin{array}{llll}\text { kaan-at } & \text { il-fataat-u } & \text { tusaaedu } & \text { umm-a-ha. } \\ \text { was-f } & \text { the-girl-nom } & \text { help } & \text { mother-acc-her }\end{array}$

'The girl was helping her mother.'
laysa l-walad-u
musaaedan li-umm-i-hi.
isn't-m
the-boy-nom
helping
for-mother-gen-his
'The boy is not helping his mother.'

Also, while tense is expressed on the auxiliary verb, the main verb appears in the imperfective form, lacking tense and dependent on the auxiliary verb for its tense: 
152 Syntactic Mapping of Preverbal Subject Positions in Standard Arabic

(50) kaan-a 1-walad-u yalabu fi 1-hadeeqat-i. was-m the-boy-nom play in the-park-gen 'The boy was playing in the park.'

(51) *kaan-a l-walad-u layba fi 1-hadeeqat-i. was-m the-boy-nom played in the-park-gen 'The boy was playing in the park.'

It is clear that the subject in Standard Arabic can precede the verb and surface in a position between the auxiliary and the verb. In this position, the subject agrees in number only with the main verb and agrees in gender with the main verb as well as the auxiliary:

$$
\begin{aligned}
& \text { kaan-a 1-awlaad-u yalab-uuna fi 1-hadeeqat-i. } \\
& \text { was-m the-boys-nom play-m.pl in the-park-gen } \\
& \text { 'The boys were playing in the park.' }
\end{aligned}
$$

However, the subject can precede both the auxiliary and the main verb and in this position it agrees in number and gender with the auxiliary as well as the main verb:

$$
\begin{aligned}
& \text { al-awlaad-u kaan-uu yalab-uuna fi l-hadeeqat-i. } \\
& \text { the-boys-nom were-m.pl play-m.pl in the-park-gen } \\
& \text { 'The boys were playing in the park.' }
\end{aligned}
$$

The preverbal DP in the example above cannot be a topic/CLLD for two reasons. The first is that the DP agrees in number and gender with the auxiliary as well as the main verb, hence the ungrammaticality of the sentence below when the subject agrees only with the main verb: 


\begin{tabular}{|c|c|c|}
\hline $\begin{array}{l}\text { *al-awlaad-u } \\
\text { the-boys-nom }\end{array}$ & $\begin{array}{l}\text { kaan-a } \\
\text { were-m }\end{array}$ & $\begin{array}{l}\text { yalab-uuna } \\
\text { play-m.pl }\end{array}$ \\
\hline
\end{tabular}

Under the assumption that the DP in the sentence above is a topic, the ungrammaticality of this sentence is hard to explain. In addition, the sentence above can be preceded by a complementiser, suggesting that the preverbal DP is a subject residing in a position below CP:

inna al-awlaad-a kaan-uu $\quad \begin{aligned} & \text { yalab-uuna } \\ & \text { fi }\end{aligned}$ 1-hadeeqat-i.
C the-boys-acc
'Indere-m.pl the boys were playing in the park.'

It is clear from the examples above that there exist two different positions for the preverbal subject when it appears with auxiliaries. The first position is between the sentence-initial auxiliary and the verb, and the second position is in a specifier position above the auxiliary.

\subsection{A New Analysis}

It has been assumed in the literature that preverbal subjects in Standard Arabic are uniformly positioned in spec-TP (or spec-AgrsP in the old configuration). In this paper, I provide an alternative analysis in which I claim that there exist two different positions for the preverbal subject in this language. The lower position is spec-TP which hosts grammatical subjects that have moved from their baseposition in spec-vP. The higher position is spec-SubjP which hosts subjects of predication, along lines discussed in Cardinaletti (2004). Crucially, subjects in spec-SubjP are base-positioned and have not 
154 Syntactic Mapping of Preverbal Subject Positions in Standard Arabic

undergone movement from spec-vP:

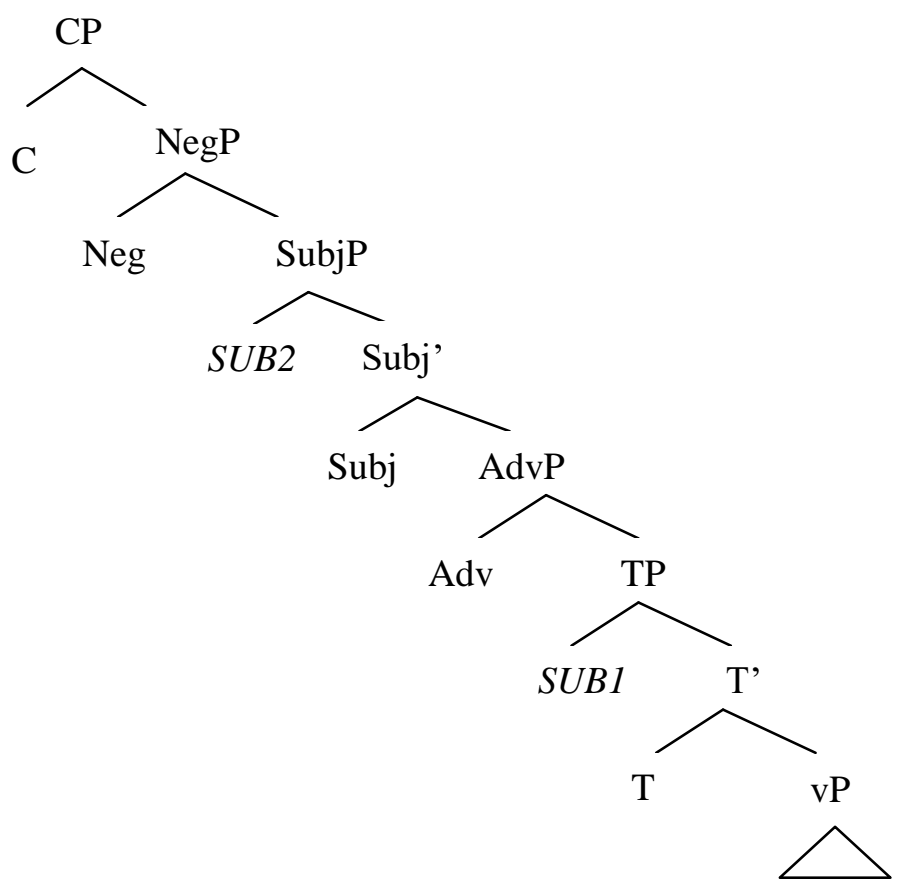

The tree diagram above shows that the SubjP projection is positioned below CP and above TP and can be preceded by a NegP projection that hosts the sentential negation particle in Standard Arabic. I argue that this configuration can account for the instances discussed in this paper where the subject seems to be in a position higher than TP. The new analysis can also account for instances in which the preverbal subject surfaces with an accusative Case marker or a genitive Case marker, indicating that the variation in Case markers is not due to the existence of different Case assigners or the 
optionality in Case marking. Rather, this analysis offers a new account for Case variation in terms of availability of syntactic positions. When the spec-SubjP position is available, it is filled with a subject of predication where this subject is base-positioned in this location. Crucially, the accusative Case on the preverbal subject in this position is inherent and has not been assigned by the head $\mathrm{T}^{44}$

However, the tree diagram above shows a simplistic view of the actually more intricate and rich syntactic layer between the $\mathrm{CP}$ and TP heads. A syntactic mapping of all the possible categories that can project between these heads will give us a better understanding of the cartography of the CP-TP area (Rizzi 1997, Cinque 1999, Cardinaletti 2004). This will also show that the two proposed positions for the preverbal subject are not adjacent as it may appear.

A closer examination and representation of the sentences below where several syntactic categories can surface in preverbal positions in Standard Arabic show that the area between the CP and TP projections can host many functional heads. ${ }^{45}$ Let us examine the position of the preverbal subject alawlaad 'the boys' in the following

\footnotetext{
44 An anonymous reviewer has put forth the possibility of attributing the accusative Case on the preverbal subject to complementisers in the language like inna 'that'. Actually, this has been the only explanation in the literature for the accusative Case on subject DPs (Fassi Fehri 1993, Benmamoun 2000, among others). The novelty in my account is in suggesting that the accusative Case on the subject is inherent and it comes as a by-product of establishing that these preverbal subjects are base-positioned, not moved, and lack any Case assigner. If one assumes that the accusative Case on the subject can be assigned by a complementiser, other cases of having accusative subjects where there are no complementisers, e.g., when these subject DPs are preceded by negation markers, cannot be explained.

45 An anonymous reviewer has pointed out that topicalisation and focalisation are not discussed here. It is to be noted that the analysis developed in this paper does not map the functional heads in the left periphery in this language and the proposed tree diagram of functional heads is by no means exhaustive. Standard Arabic can have TopP and FocP projections where Topics can appear with a nominative Case and leave a pronominal clitic as in CLLD constructions.
} 
sentences. Each sentence is followed by a representation of the possible hierarchy of its syntactic categories:
a. al-awlaad-u
yalab-uun fi
the-boys-nom
play-pl
1-hadeeqat-i
Kullayoum.
the-garden-gen
everyday
'The boys play in the garden everyday.'
b. $\mathrm{TP}>\mathrm{vP}$

(58)
a. kaana 1-awlaad-u yalab-uun
was the-boys-nom play-pl
fi 1-hadeeqat-i.
in the-garden-gen

'The boys were playing in the garden.'

b. AuxP $>$ TP $>$ vP

(59) a. al-awlaad-u kaanu yalab-uun fi 1-hadeeqat-i.

the-boys-nom were play-pl in the-garden-gen 'The boys were playing in the garden.'

b. SubjP $>$ AuxP $>$ TP $>$ vP

(60)
a. al-awlaad-u lam yakuunu
the-boys-nom not were
yalab-uun fi 1-hadeeqat-i.
play-pl in the-garden-gen
'The boys were not playing in the garden.'
b. SubjP $>$ NegP $>$ AuxP $>$ TP $>$ vP 
(61)

$\begin{array}{lll}\text { a. al-awlaad-u } & \text { lam } & \text { yakuunu daaeman } \\ \text { the-boys-nom } & \text { not } & \text { were always } \\ \text { yalab-uun } & \text { fi } & \text { l-hadeeqat-i. } \\ \text { play-pl } & \text { in } & \text { the-garden-gen }\end{array}$

'The boys were not always playing in the garden.'

b. SubjP $>$ NegP $>$ AuxP $>$ AdvP $>$ TP $>$ vP

(62)
a. al-awlaad-u
$\begin{array}{lll}\text { ghaleban } & \text { lam } & \text { yakuunu } \\ \text { often } & \text { not } & \text { were }\end{array}$
the-boys-nom
fi
1-hadeeqat-i.
yalab-uun
in
the-garden-gen
play-pl
in
'The boys often were not playing in the garden.'
b. SubjP $>$ AdvP $>$ NegP $>$ AuxP $>$ TP $>$ vP

(63) a. al-awlaad-u sawfa yalab-uun fi 1-hadeeqat-i. the-boys-nom will play-pl in the-garden-gen 'The boys will play in the garden.'

b. SubjP $>$ ModP $>$ TP $>$ vP

(64)
a. al-awlaad-u
sawfa
lan
the-boys-nom
will
not
yalab-u
fi
1-hadeeqat-i.
play-pl
in
the-garden-gen

'The boys will not play in the garden.'

b. SubjP $>$ ModP $>$ NegP $>$ TP $>$ vP

(65)

$\begin{array}{lll}\text { a. la } & \text { awlaad-a sawfa } & \text { yalab-uun } \\ \text { not } & \text { boys-acc will } & \text { play-pl } \\ \text { fi } & \text { l-hadeeqat-i. } & \\ \text { in } & \text { the-garden-gen } & \end{array}$


158 Syntactic Mapping of Preverbal Subject Positions in Standard Arabic

'No boys will play in the garden.'

b. NegP $>$ SubjP $>$ ModP $>$ TP $>$ vP

(66)

$\begin{array}{llll}\text { a. inna-hum } & \text { haqqan } & \text { sawfa lan } \\ \text { C-they } & \text { really } & \text { will } \\ \text { yalab-u } & \text { fi } & \text { l-hadeeqat-i. } \\ \text { play-pl } & \text { in } & \text { the-garden-gen }\end{array}$

'Indeed, they really will not play in the garden.'

b. $\mathrm{CP}>\mathrm{SubjP}>\mathrm{AdvP}>\mathrm{ModP}>\mathrm{NegP}>\mathrm{TP}>\mathrm{vP}$

A collapsed hierarchical representation of all the sentences above will give us the following tree diagram:

(67)

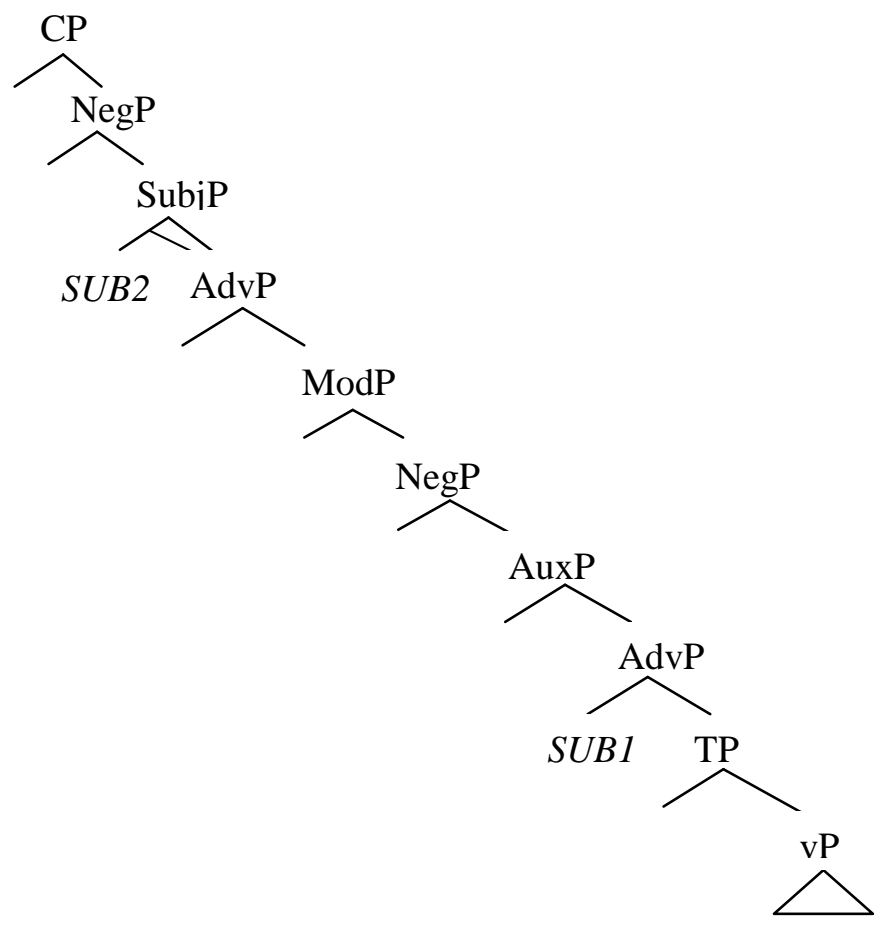


It should be noted that the tree diagram above is not exhaustive. However, it maps the major syntactic categories that can project in the layer between the CP and TP. It is to be noticed that negation particles occupy two different positions. Additionally, adverbs are shown to occupy two positions as well; however, the hierarchy of all types of adverbs in this language is beyond the scope of this paper (cf. Cinque 1999).

\section{On Two Preverbal DPs}

In this section, I provide further evidence to support my assumption that there exist two preverbal subject positions in Standard Arabic through investigating certain contexts in this language in which two preverbal DPs can surface at the same time, suggesting that there are two different positions that can host preverbal subjects.

\subsection{Floating Quantifiers}

The concurrence of the subject and a floating quantifier in a preverbal position needs further investigation on the possible positions of both DPs. In standard Arabic, quantifiers like kullu and jameeu typically precede the quantified DP which surfaces with a genitive Case marker (Aoun et al. 2010, Fassi Fehri 2012):

$$
\begin{array}{llll}
\text { kullu } & \text { t-tullaab-i } & \text { hadhar-uu } & \text { n-nadwat-a. } \\
\text { all } & \text { the-students-gen } & \text { attended-pl } & \text { the-semianr-acc }
\end{array}
$$

'All the students attended the seminar.' 
160 Syntactic Mapping of Preverbal Subject Positions in Standard Arabic

(69) jameeu t-tullaab-i hadhar-uu n-nadwat-a.

all the-students-gen attended-pl the-semianr-acc

'All the students attended the seminar.'

Any alternative order between the quantifier and the DP renders the sentences ungrammatical:

(70) *at-tullaab-i kullu hadhar-uu n-nadwat-a. the-students-gen all attended-pl the-semianr-acc 'All the students attended the seminar.'

$\begin{array}{llll}* \text { at-tullaab-i } & \text { jameeu } & \text { hadhar-uu } & \text { n-nadwat-a. } \\ \text { the-students-gen } & \text { all } & \text { attended-pl } & \text { the-semianr-acc }\end{array}$
'All the students attended the seminar.'

However, the preverbal DP that follows the quantifier can be leftdislocated to a topic position, provided that it leaves a pronominal clitic attached to the quantifier:
at-tullaab-u
kullu-hum hadhar-uu n-nadwat-a. the-students-gen all-they attended-pl the-semianr-acc 'The students, all of them attended the seminar.'
at-tullaab-u jameeu-hum
hadhar-uu n-nadwat-a. the-students-gen all-they attended-pl the-semianr-acc 'The students, all of them attended the seminar.'

On the other hand, floating quantifiers like ajmauun and kaafatan cannot precede DPs, hence the ungrammaticality of the sentences below: 
(74)

*ajmauun t-tullaab-i hadhar-uu n-nadwat-a.

all the-students-gen attended-pl the-semianr-acc

'All the students attended the seminar.'

(75)

*kaafatan t-tullaab-i hadhar-uu n-nadwat-a.

all the-students-gen attended-pl the-semianr-acc

'All the students attended the seminar.'

Floating quantifiers like ajmauun and kaafatan must follow the quantified DP (Ryding 2005):

(76) at-tullaab-u ajmauun hadhar-uu n-nadwat-a.

the-students-nom all attended-pl the-semianr-acc

'The students all attended the seminar.'

(77) at-tullaab-u kaafatan hadhar-uu n-nadwat-a.

the-students-nom all attended-pl the-semianr-acc

'The students all attended the seminar.'

The preverbal DPs above cannot be assumed to be an instance of left-dislocated structures. In this language, left-dislocated or topicalised DPs usually leave behind a resumptive pronoun. If one assumes that the preverbal DP in the sentences above is a topic, the ungrammaticality of the sentences below is hard to explain where a resumptive pronoun appears attached to the quantifier:

*at-tullaab-u ajmaunn-hum hadhar-uu n-nadwat-a.
the-students-nom all attended-pl the-semianr-acc
'The students all attended the seminar.'


162 Syntactic Mapping of Preverbal Subject Positions in Standard Arabic

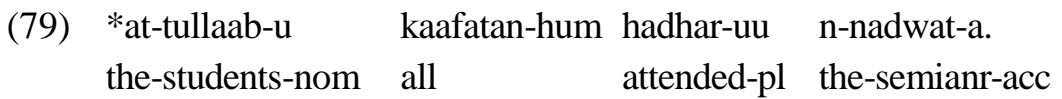
'The students all attended the seminar.'

However, the preverbal DP in the sentences above can be topicalised and moved to a position above $\mathrm{C}$. In this context, it must leave a resumptive pronoun in its base-position in spec-SubjP:

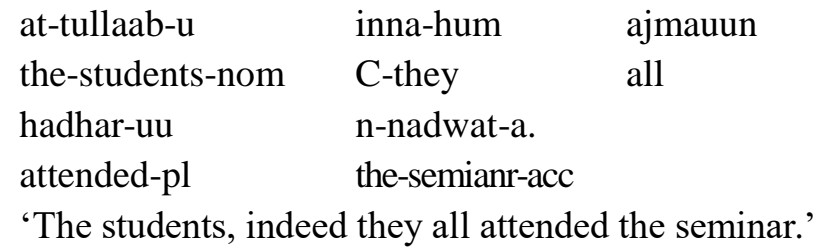

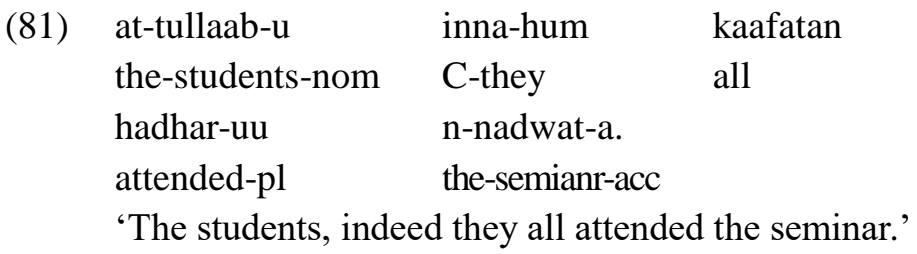

Contrary to the assumption that the two preverbal XPs following the head $\mathrm{C}$ are both competing for the same position, i.e., spec-TP, I argue that the preverbal resumptive pronoun and the floating quantifier in the sentences above occupy two different syntactic positions. These positions are spec-SubjP for the resumptive pronoun and spec-TP for the quantifier.

\subsection{Emphatic Reflexives}

In Standard Arabic, the preverbal subject can surface with an 
emphatic reflexive:

(82) al-walad-u nafsuhu katab-a haatha 1-maqaal-a. the-boy-nom himself wrote-sg this the-essay-acc 'The boy himself wrote this essay.'

(83) al-awlaad-u anfusuhum hadhar-uu n-nadwat-a. the-boys-nom themselves attended-pl the-seminar 'The boys themselves attended the seminar.'

In addition, the preverbal DP and the reflexive can be both preceded by a complementiser:

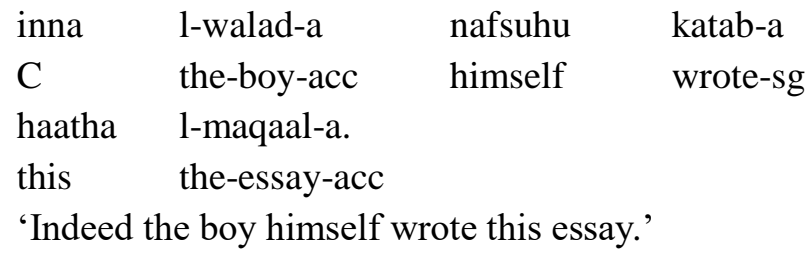

(85) inna l-awlaad-a anfusuhum hadhar-uu n-nadwat-a. C the-boys-acc themselves attended-pl the-seminar-acc 'Indeed the boys themselves attended the seminar.'

Moreover, the preverbal DP can be topicalised and moved to a position above the complementiser. In this context, it must leave a resumptive pronoun in its base-position, giving us two preverbal pronominals, a resumptive pronoun and a reflexive pronoun:

$$
\begin{array}{llll}
\text { al-walad-u } & \text { inna-hu } & \text { nafsuhu } & \text { katab-a } \\
\text { the-boy-nom } & \text { C-he } & \text { himself } & \text { wrote-sg }
\end{array}
$$


164 Syntactic Mapping of Preverbal Subject Positions in Standard Arabic

$\begin{array}{ll}\text { haatha } & \text { 1-maqaal-a. } \\ \text { this } & \text { the-essay-acc }\end{array}$

'The boy, indeed he himself wrote this essay.'

(87) al-awlaad-u inna-hum anfusuhum

the-boys-nom C-they themselves

hadhar-uu n-nadwat-a.

attended-pl the-seminar-acc

'The boys, indeed they themselves attended the seminar.'

It is clear from the examples above that the two preverbal pronominals occupy two different syntactic positions between $\mathrm{C}$ and $\mathrm{T}$, assuming that the verb in Standard Arabic uniformly left-adjoins the head T. Our assumption that a SubjP projection above T can host subjects of predication accounts for this context where two XPs seem to be competing for the subject position.

\subsection{Apposition}

In Standard Arabic, two different DPs which refer to the same entity/person can surface side by side:

Amr-un al-malek al-mashhoor kaana shujaan. Amr-nom the-king the-famous was brave 'Amr the famous king was brave.'

(89) Hind-u al-malekatu 1-hakeema hakamat al-belaad-a. Hind-nom the-queen the-wise ruled the-country-acc 'Hind the wise queen ruled the country.' 
In addition, a subject DP in this language can be mentioned twice for emphasis:

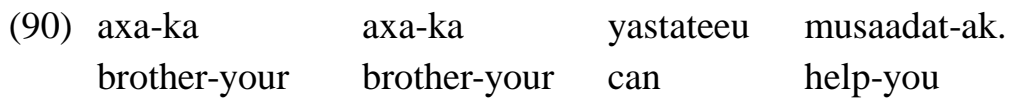
'Your brother your brother can help you.'

(91) al-kaateb-u l-kaateb-u nashara maqaal-an. the-author-nom the-author-nom published essay-acc 'The author the author published an essay.'

Moreover, a DP and a pronoun can refer to the same person and surface together:

$\begin{array}{llll}\text { nahnu } & \text { l-mualem-uun } & \text { nuhebu } & \text { t-tadrees-a. } \\ \text { we } & \text { the-teachers-nom } & \text { like } & \text { the-teaching-acc }\end{array}$

'We the teachers like to teach.'

(93) hua 1-jundi yudafe aan il-watan-i.

he the-soldier defend about the-homeland-gen

'He the soldier defends the homeland.'

Apparently, Standard Arabic can have several contexts in which two XPs appear side by side in a preverbal position. Different accounts have been proposed in the literature to accommodate these two adjacent DPs in terms of topicalisation or focalization of the higher DP. I contribute to this ongoing investigation by introducing a new analysis in which I assume that there exist two different preverbal subject positions that can host different preverbal DPs. The two positions are spec-TP, for the grammatical subject which moves 
from spec-vP, and spec-SubjP, which hosts base-positioned XPs.

\section{Conclusions}

In this paper, I introduce a new analysis of preverbal subject positions in Standard Arabic based on the recent literature on the cartography of syntax (Belletti 2004, Cardinaletti 2004, Rizzi 2004, among others). I argue that preverbal Subjects in this language can surface in two different syntactic positions. The first position is specTP where a grammatical subject that has moved from spec-vP can be hosted. The second position is the specifier position of a new projection SubjP which can host base-positioned subjects of predication, along lines discussed in Caredinaletti (2004). A clear picture of this assumption is attained when we conduct a detailed investigation of the hierarchical relation of the subject with other syntactic categories that can project between CP and TP. These categories include negation, auxiliaries, adverbs, quantifiers, reflexives, and appositions. The aim of this investigation is to determine the inventory and hierarchies of these syntactic categories and to contribute to the current debate on the cartography of clause structure. 


\section{References}

Aoun, J., E. Benmamoun \& L. Choueiri. 2010. The Syntax of Arabic. Cambridge: Cambridge University Press.

Belletti, A. 2004. Aspects of the Low IP Area. In L. Rizzi (ed.), The Structure of CP and IP 16-51. Oxford: Oxford University Press.

Benmamoun, E. 2000. The Feature Structure of Functional Categories: A Comparative Study of Arabic Dialects. Oxford: Oxford University Press.

Cardinaletti, A. 1997. Subjects and Clause Structure. In L. Haegeman (ed.), The New Comparative Syntax 33-63. London: Longman. 2004. Towards a Cartography of Subject Positions. In L.

Rizzi (ed.), The Structure of CP and IP 115-165. Oxford: Oxford University Press.

Chomsky, N. 2001. Derivation by Phase. In M. Kenstowicz (ed.),

Ken Hale: A Life in Language 1-52. Cambridge, MA: MIT Press. 2008. On Phases. In C. Otero et al. (eds.), Foundational

Issues in Linguistic Theory. Essays in Honor of Jean-Roger Vergnaud 134-166. Cambridge, MA: MIT Press.

Cinque, G. 1999. Adverbs and Functional Heads. Oxford: Oxford University Press.

Fassi Fehri, A. 1993. Issues in the Structure of Arabic Clauses and Words. Dordrecht: Kluwer. 2012. Key Features and Parameters in Arabic Grammar. Amsterdam: John Benjamins.

Kotzoglou, G. 2006. Subject-Verb Inversion in Greek: Implications for Head Movement and Typology. Journal of Universal Language 7.1, 91-137.

McCloskey, J. 1997. Subjects and Subject Positions. In L. Haegeman (ed.), Elements of Grammar 197-235. Dordrecht: Kluwer. 
168 Syntactic Mapping of Preverbal Subject Positions in Standard Arabic

Ouhalla, J. 1994. Verb Movement and Word Order in Arabic. In D. Lightfoot \& N. Hornstein (eds.), Verb Movement 41-72. Cambridge: Cambridge University Press.

Rizzi, L. 1997. The Fine Structure of the Left Periphery. In L. Haegeman (ed.), Elements of Grammar: Handbook in Generative Syntax 281-337. Dordrecht: Kluwer. . 2004. On the Cartography of Syntactic Structures. In L. Rizzi (ed.), The Structure of CP and IP 3-15. Oxford: Oxford University Press.

Ryding, K. 2005. A Reference Grammar of Modern Standard Arabic. Cambridge: Cambridge University Press.

Shlonsky, U. 1997. Clause Structure and Word Order in Hebrew and Arabic: An Essay in Comparative Semitic Syntax. Oxford: Oxford University Press. 